\title{
Allogeneic Hematopoietic Stem-Cell Transplantation for Sickle Cell Disease
}

\author{
Matthew M. Hsieh, M.D., Elizabeth M. Kang, M.D., Courtney D. Fitzhugh, M.D., M. Beth Link, \\ R.N., Charles D. Bolan, M.D., Roger Kurlander, M.D., Richard W. Childs, M.D., Griffin P. \\ Rodgers, M.D., Jonathan D. Powell, M.D., Ph.D., and John F. Tisdale, M.D. \\ Molecular and Clinical Hematology Branch, National Institute of Diabetes and Digestive and \\ Kidney Diseases and National Heart, Lung, and Blood Institute (M.M.H., C.D.F., M.B.L., G.P.R., \\ J.F.T.); the Laboratory of Host Defenses, National Institute of Allergy and Infectious Diseases \\ (E.M.K.); the Hematology Branch, National Heart, Lung, and Blood Institute (C.D.B., R.W.C.); and \\ the Department of Laboratory Medicine, Clinical Center (R.K.) - all in Bethesda, MD; and the \\ Sidney Kimmel Comprehensive Cancer Center at Johns Hopkins, Baltimore (J.D.P.)
}

\begin{abstract}
BACKGROUND-Myeloablative allogeneic hematopoietic stem-cell transplantation is curative in children with sickle cell disease, but in adults the procedure is unduly toxic. Graft rejection and graft-versus-host disease (GVHD) are additional barriers to its success. We performed nonmyeloablative stem-cell transplantation in adults with sickle cell disease.
\end{abstract}

\begin{abstract}
METHODS-Ten adults (age range, 16 to 45 years) with severe sickle cell disease underwent nonmyeloablative transplantation with CD34+ peripheral-blood stem cells, mobilized by granulocyte colony-stimulating factor (G-CSF), which were obtained from HLA-matched siblings. The patients received $300 \mathrm{cGy}$ of total-body irradiation plus alemtuzumab before transplantation, and sirolimus was administered afterward.
\end{abstract}

\begin{abstract}
RESULTS-All 10 patients were alive at a median follow-up of 30 months after transplantation (range, 15 to 54). Nine patients had long-term, stable donor lymphohematopoietic engraftment at levels that sufficed to reverse the sickle cell disease phenotype. Mean $( \pm \mathrm{SE})$ donor-recipient chimerism for T cells (CD3+) and myeloid cells (CD14+15+) was $53.3 \pm 8.6 \%$ and $83.3 \pm 10.3 \%$, respectively, in the nine patients whose grafts were successful. Hemoglobin values before transplantation and at the last follow-up assessment were $9.0 \pm 0.3$ and $12.6 \pm 0.5 \mathrm{~g}$ per deciliter, respectively. Serious adverse events included the narcotic-withdrawal syndrome and sirolimusassociated pneumonitis and arthralgia. Neither acute nor chronic GVHD developed in any patient.
\end{abstract}

CONCLUSIONS-A protocol for nonmyeloablative allogeneic hematopoietic stem-cell transplantation that includes total-body irradiation and treatment with alemtuzumab and sirolimus can achieve stable, mixed donor-recipient chimerism and reverse the sickle cell phenotype.

Sickle cell disease results from a single nucleotide substitution in which valine replaces glutamic acid at the sixth position of the $\beta$-globin chain of hemoglobin A. ${ }^{1,2}$ This change causes a propensity toward polymerization of hemoglobin and, hence, sickle-shaped red cells. Anemia, increased hemolysis, and acute and chronic vaso-occlusive complications that affect multiple organs are the main features of sickle cell disease. At present, allogeneic

Copyright $\odot 2009$ Massachusetts Medical Society. All rights reserved.

Address reprint requests to Dr. Tisdale at 9000 Rockville Pike, Bldg. 10, Rm. 9N 116, Bethesda, MD 20892, or at johntis@mail.nih.gov.

No potential conflict of interest relevant to this article was reported. 
hematopoietic stem-cell transplantation is the only curative option. ${ }^{3-5}$ Approximately 200 children have undergone this procedure after myeloablative conditioning with busulfan and cyclophosphamide, with or without antithymocyte globulin, resulting in a rate of diseasefree survival of $95 \%$ in the most recent series. ${ }^{5}$ After transplantation, the donor's hematopoietic cells completely replace those of the recipient in most children who undergo this procedure, but some continue to have both recipient and donor cells in the blood (mixed chimerism). ${ }^{6}$ This mixture is sufficient to reverse the sickle cell disease phenotype.

The development of safe, nonmyeloablative conditioning regimens that allow stable, mixed chimerism could facilitate allogeneic stem-cell transplantation in adults with severe sickle cell disease, in whom the toxicity of myeloablative conditioning can be prohibitive. Early attempts at such conditioning in sickle cell disease did not, however, reliably achieve longterm engraftment of donor cells. ${ }^{7}$ Sustained engraftment of allogeneic stem cells in patients with other diseases after minimally toxic nonmyeloablative conditioning with fludarabine and cyclophosphamide has been reported, ${ }^{8,9}$ although the mixed-chimeric state was temporary. In most cases, alloreactive donor T cells eradicated the recipient's stem cells, and the rates of graft-versus-host disease (GVHD), morbidity, and mortality were high. ${ }^{8,9}$

We sought to develop a means for performing hematopoietic stem-cell transplantation in adults with sickle cell disease that would allow engraftment and avoid GVHD in the presence of allogeneic donor T cells. On the basis of a novel mechanism for inducing immunologic tolerance, we chose low-dose radiation plus sirolimus (formerly known as rapamycin). Unlike calcineurin inhibitors such as cyclosporine, sirolimus does not block the process of T-cell activation through the T-cell receptor but rather inhibits T-cell proliferation by binding to the mammalian target of rapamycin. Activated $\mathrm{T}$ cells that cannot proliferate become anergic, and this property can promote T-cell tolerance. ${ }^{10} \mathrm{We}$ showed the feasibility of this approach in a murine model in which we administered a short course of either cyclosporine or sirolimus after a single dose of total-body irradiation (300 cGy). Long-term, high-level chimerism was attained only in the mice treated with sirolimus. This method can correct the sickle cell disease phenotype in transgenic mice with the sickle cell gene. ${ }^{11}$ Here we describe our results with the application of this approach in 10 adults with severe sickle cell disease.

\section{METHODS}

\section{STUDY DESIGN AND PROCEDURES}

We conducted a phase 1-2 study to determine the feasibility of nonmyeloablative allogeneic hematopoietic stem-cell transplantation for adults with severe sickle cell disease. It was approved by the institutional review board of the National Heart, Lung, and Blood Institute and was monitored by an independent data and safety monitoring board.

Patients 16 years of age or older were eligible for enrollment if they were homozygous for hemoglobin S or compound heterozygous for hemoglobins S and C, as confirmed by results on hemoglobin electrophoresis, identification of an HLA-identical family donor, and the presence of severe disease (Table 1). Written informed consent or assent was obtained for all patients and donors. Inclusion criteria were a severe end-organ complication (previous cerebrovascular event, sickle-cell nephropathy, or elevated tricuspid regurgitant jet velocity) $3,12,13$ or a potentially reversible complication (frequent vaso-occlusive crises, the acute chest syndrome, osteonecrosis, or red-cell alloimmunization) ${ }^{3-5}$ that was not ameliorated by treatment with hydroxyurea.

HLA typing at the molecular level was performed, and all donors were fully matched. Donors underwent 5 to 6 days of granulocyte colony-stimulating factor (G-CSF) 
mobilization (10 to $16 \mu \mathrm{g}$ per kilogram of body weight per day), followed by large-volume leukapheresis, with the goal of collecting at least $10 \times 10^{6} \mathrm{CD} 34+$ cells per kilogram of the recipient's body weight; the donor's cells were cryopreserved. ${ }^{14}$ The conditioning regimen for the recipient consisted of alemtuzumab, $1 \mathrm{mg}$ per kilogram (total dose) given in gradually increasing doses on days 7 to 3 before transplantation, a single dose of $300 \mathrm{cGy}$ of total-body irradiation on day 2 before transplantation, and oral sirolimus starting the day before transplantation (Fig. 1A). Alemtuzumab, a humanized monoclonal antibody directed against CD52 (expressed on lymphocytes), depletes T cells and B cells. It does not affect the development of hematopoietic stem cells ${ }^{17}$ and has been used to prevent GVHD. ${ }^{18,19}$ Tapering of sirolimus was to be initiated when donor chimerism reached $100 \%$.

\section{SUPPORTIVE CARE}

We followed standardized, intramural guidelines for supportive care established at our facility for patients undergoing allogeneic hematopoietic stem-cell transplantation, with several modifications specific for sickle cell disease. Recipients were maintained on hydroxyurea until 24 hours before starting the preparative regimen. Red-cell exchange was performed to reduce hemoglobin S levels to $30 \%$ or less before the preparative regimen. Platelet and red-cell transfusions were used to maintain the platelet count at $50 \times 10^{9}$ per liter or more and the hemoglobin level at 9 to $10 \mathrm{~g}$ per deciliter. G-CSF was not administered because of its association with complications and death in sickle cell disease. Penicillin V potassium, $250 \mathrm{mg}$, was given twice daily from day 0 until pneumococcal vaccination was completed.

\section{ANALYSIS FOR CHIMERISM}

Engraftment of donor cells was assessed with the use of methods that detect informative polymorphisms in regions known to contain short tandem repeats. ${ }^{20}$ Peripheral-blood CD3+ T cells and CD14+CD15+ myeloid cells were selected for analysis with the use of immunomagnetic beads (Dynal). On the basis of studies using mixtures of known proportions of allogeneic DNA samples, the lower limit of sensitivity for this method is 1 to $3 \%$ of donor-type polymorphic markers in the mixture. ${ }^{20}$

\section{STATISTICAL ANALYSIS}

Means $( \pm \mathrm{SE})$ were calculated for chimerism, hemoglobin values, and hemolytic variables. A paired t-test was used to compare data obtained before and after transplantation.

\section{RESULTS}

\section{CHARACTERISTICS OF PATIENTS AND TRANSPLANTS}

During the 5 years of recruitment, we performed HLA typing on 169 siblings and 112 patients with sickle cell disease. ${ }^{15,16}$ Of the 24 eligible recipients, 10 have undergone transplantation to date (Fig. 1B). Table 1 summarizes the clinical information and indications for these 10 patients, who ranged in age from 16 to 45 years (median, 26). One patient had hemoglobin SC; the other nine had hemoglobin SS. All donors, including those with sickle cell trait, tolerated G-CSF mobilization without adverse events, which yielded 5.51 million to 28.2 million CD34+ cells per kilogram of the recipient's body weight. There were no technical difficulties in thawing stem cells collected from donors with sickle cell trait. ${ }^{14}$ Recipients received 5.51 million to 23.8 million CD34+ cells per kilogram of body weight.

All recipients tolerated the conditioning regimen. The median duration of neutropenia (defined as a neutrophil count of less than $0.5 \times 10^{9}$ cells per liter) was 15.5 days (range, 10 to 21) (Fig. 2 and Table 2). Only three patients had a neutrophil count below $0.1 \times 10^{9}$ cells 
per liter, which was the nadir value lasting for 1,4 , and 7 days. The median duration of lymphopenia $\left(<0.75 \times 10^{9}\right.$ cells per liter) was 4 months (range, 1.5 to 8$)$, and thrombocytopenia $\left(<50 \times 10^{9}\right.$ cells per liter) lasted a mean of 7 days (range, 1 to 19$)$. The median numbers of packed red-cell units and single-donor apheresis platelet units were 6.5 (range, 4 to 11) and 5.5 (range, 1 to 9), respectively. Intravenous antibiotics were administered for a median of 7 days (range, 0 to 15). No patient received antimicrobial agents for presumed fungal disease, and there was no need for parenteral nutrition.

\section{OUTCOMES}

All 10 patients were alive at a median follow-up of 30 months (range, 15 to 54) (Table 2). The graft was retained in nine of the patients. At a median of 30 months after transplantation among these nine recipients, the mean percentage of circulating donor $\mathrm{T}$ cells was $53.3 \pm 8.6 \%$ (range, 7 to 72 ), and the mean percentage of circulating donor myeloid cells was $83.3 \pm 10.3 \%$ (range, 19 to 100 ). The increase in circulating donor myeloid cells was more rapid than the increase in donor T cells (Fig. 3A, and Fig. 1 in the Supplementary Appendix, available with the full text of this article at NEJM. org). Since no patient reached $100 \%$ donor chimerism in T cells, sirolimus therapy was continued throughout the study. Patients 5 and 8 had undetectable levels of sirolimus on multiple occasions during the most recent 6 months and acknowledged noncompliance with sirolimus therapy.

Hemoglobin levels gradually improved after transplantation (Fig. 3B, and Fig. 1 in the Supplementary Appendix). Respective mean hemoglobin levels for women and men were $8.8 \pm 0.3$ and $9.3 \pm 0.5 \mathrm{~g}$ per deciliter before transplantation and $12.6 \pm 0.6$ and $12.7 \pm 1.1 \mathrm{~g}$ per deciliter at the most recent follow-up. To date, four patients have completed therapeutic phlebotomy to correct transfusion- related iron overload, and four more are undergoing this treatment. Hemoglobin electrophoreses performed on blood samples collected 6 months or more after transplantation showed the same percentage of hemoglobin $\mathrm{S}$ as in the donors for all these patients except Patient 2 (Table 3).

Markers of increased hemolysis declined (Fig. 3C, and Fig. 1 in the Supplementary Appendix). The respective mean values before and after transplantation were as follows: reticulocyte counts, $200 \pm 35 \times 10^{9}$ per liter and $60 \pm 12 \times 10^{9}$ per liter; total bilirubin levels, $3.03 \pm 0.72$ and $0.69 \pm 0.28 \mathrm{mg}$ per deciliter; and lactate dehydrogenase levels, $302 \pm 48$ and $186 \pm 17$ units per liter.

Patients with a history of cerebrovascular injury before transplantation did not have cerebrovascular events after transplantation. The findings on brain magnetic resonance imaging and magnetic resonance angiography remained stable at 1 and 2 years after transplantation in patients with abnormalities on brain imaging. Patients with elevated tricuspid regurgitant jet velocity or a history of the acute chest syndrome had no episodes of dyspnea or documented declines in oxygenation during conditioning. The mean tricuspid regurgitant jet velocity before transplantation $(2.8 \pm 0.1 \mathrm{~m}$ per second $)$ did not differ significantly from the mean values 1,12 , and 24 months after the transplantation (Table 1 in the Supplementary Appendix). Although a 6-minute walk test was not performed routinely before transplantation, values after transplantation compared favorably with those in historical controls at our institution. ${ }^{21}$ In three patients with sickle cell nephropathy and proteinuria, the slope of decline in renal function did not exceed the slope before the transplantation. Patient 3 became pregnant 30 months after the transplantation; she delivered a healthy daughter at 38 weeks of gestation (Table 2 in the Supplementary Appendix). 


\section{ADVERSE EVENTS}

Table 3 summarizes the adverse events. Acute or chronic GVHD did not develop in any patient.

Only one of the nine patients for whom the donor, recipient, or both were positive for cytomegalovirus (CMV) had reactivated CMV infection. One seropositive recipient with a seropositive donor had transient reactivation of CMV infection at approximately day 14 after transplantation, while receiving valacyclovir; the infection resolved after 1 week of intravenous foscarnet therapy and maintenance treatment with valacyclovir.

Six patients had minor ankle arthralgia and nonpitting edema, starting approximately 1 month after transplantation and continuing for approximately 5 months. These events were attributed to the administration of sirolimus. Two patients had arthralgia severe enough to alter activities of daily living: one was admitted to the hospital to rule out causes other than sirolimus and the other was treated as an outpatient. In both patients, the symptoms resolved with supportive care and a reduced dose of sirolimus to obtain trough levels of 5 to $10 \mathrm{ng}$ per milliliter. Two patients presented with exertional dyspnea 4 and 16 months after transplantation; pulmonary-function tests showed obstructive and restrictive abnormalities. After infection had been ruled out, sirolimus-associated pneumonitis was diagnosed in both patients. Cyclosporine was substituted for sirolimus in one patient, ${ }^{22}$ and the sirolimus dose was lowered in the other. There was complete resolution 3 months later in both patients with no further intervention.

Before transplantation, four patients had a clinically significant need for narcotics to alleviate recurrent pain crises. Two required repeated hospital admissions for the narcoticwithdrawal syndrome, with symptoms resembling the pain of vascular occlusion after stemcell transplantation. These episodes necessitated a gradual tapering of narcotics, which was successfully completed in all four patients approximately 6 months after transplantation (Fig. 2 in the Supplementary Appendix).

\section{DEVIATIONS IN PROTOCOL}

Patients 2 and 3 inadvertently received 200 cGy of total-body irradiation instead of the planned $300 \mathrm{cGy}$. Patient 2 had donor engraftment for about 4 months, followed by loss of the graft, autologous hematopoiesis, and recurrent sickle cell disease. One year later, after undergoing conditioning with a modified regimen consisting of $400 \mathrm{cGy}$ and the dose of alemtuzumab administered previously, he received a second transplant from the same donor; this transplantation was successful. Patient 3 has persistent stable, mixed chimerism.

\section{DISCUSSION}

Sickle cell disease affects multiple organs and shortens the life span of those affected. ${ }^{23-26}$ In our study of allogeneic hematopoietic stem-cell transplantation in 10 adults with severe sickle cell disease, the procedure itself was not associated with serious adverse events, and there were no treatment-related deaths. The duration of cytopenias was 10 to 21 days for neutropenia, 1.5 to 8 months for lymphopenia, and 1 to 19 days for thrombocytopenia. A neutrophil count nadir of less than $0.1 \times 10^{9}$ per liter, which lasted for 1 to 7 days, occurred in 3 of the 10 patients. The relatively brief periods of neutropenia probably accounted for the absence of overwhelming bacterial or invasive fungal infections in our patients. Our rate of successful engraftment ( 9 of 10 patients), is similar to the reported rates after myeloablative conditioning in children with sickle cell disease who underwent transplantation in France $(95.5 \%),{ }^{5}$ the United States (91.5\%), ${ }^{6}$ and Belgium (94\%). ${ }^{4}$ Remarkably, acute or chronic GVHD, the major contributors to the morbidity and mortality associated with stem-cell transplantation, did not occur in any of our transplant recipients during a median follow-up 
of 30 months. The absence of GVHD in our patients compares favorably with the results of myeloablative stem-cell transplantation in children with sickle cell disease, in whom the low frequency of GVHD has been attributed to age and the use of bone marrow or cord blood as stem-cell sources.

We believe that our results are due to the conditioning regimen. Total-body irradiation at a dose of $300 \mathrm{cGy}$ must have created enough bone marrow space to allow a degree of hematopoiesis from donor stem cells that was sufficient to reverse the sickle cell disease phenotype. In addition, this level of radiation supplements the immunosuppression required to prevent rejection of the allograft. Alemtuzumab, with detectable lymphocytotoxic plasma drug levels for several weeks after administration, ${ }^{27,28}$ reduced the numbers of circulating lymphocytes in the recipient before stem-cell infusion, thereby helping to prevent graft rejection, and also depleted alloreactive $\mathrm{T}$ cells after transplantation, which probably prevented the development of GVHD. Sirolimus for prophylaxis against GVHD, a relatively new use of the drug, promotes the differentiation of regulatory $\mathrm{T}$ cells and helper $\mathrm{T}$ cells, both of which play key roles in minimizing the risk of GVHD. ${ }^{29-31}$ These benefits of sirolimus in conjunction with gradual reconstitution of donor $\mathrm{T}$ cells support a graft-tolerant milieu in which stable, mixed donor-recipient chimerism was sufficient to achieve erythropoiesis entirely from donor cells. In contrast, calcineurin inhibitors inhibit the induction of immune tolerance. ${ }^{10,32}$ Most of our patients have continued to receive sirolimus because of their mixed chimeric state. Frequently reported side effects of sirolimus include myelosuppression, increased serum triglyceride levels, hypercholesterolemia, and hyperglycemia. ${ }^{33-35}$ Prolonged administration of sirolimus increases the risk of viral reactivation, opportunistic infections, pneumonitis, and post-transplantation lymphoproliferative disorder. We have not observed myelosuppression in any of the patients; we are treating hyperlipidemia in three patients. We are gradually decreasing sirolimus doses to minimize side effects and are monitoring the patients for infection, changes in organ function, and tumors. The stability of donor chimerism in the two patients who did not comply with sirolimus treatment has prompted us to amend the protocol so that the dose of sirolimus is tapered in patients in whom over $50 \%$ of $\mathrm{T}$ cells are of donor origin.

In summary, we have developed a simplified regimen of hematopoietic stem-cell transplantation that allows for stable, mixed donor-recipient chimerism and reverses the sickle cell disease phenotype. The simplicity, low toxicity, and high efficacy of this approach make it feasible for use at most transplantation centers.

\section{Supplementary Material}

Refer to Web version on PubMed Central for supplementary material.

\section{Acknowledgments}

Supported by the intramural research program of the National Institute of Diabetes and Digestive and Kidney Diseases and the National Heart, Lung, and Blood Institute at the National Institutes of Health.

We thank Terri Wakefield and Carol Boss for protocol support, the Hematology Branch staff, the pharmacy staff, the Department of Transfusion Medicine, the Dowling Apheresis and Cell Processing Sections, the Social Work Department, the language interpretation service, the Pain and Palliative Care service, and the clinical staff at the NIH Clinical Center for patient care.

\section{References}

1. Pauling L, Itano HA, Singer SJ, Wells IC. Sickle cell anemia, a molecular disease. Science. 1949; 110:543-8. [PubMed: 15395398] 
2. Ingram VM. Gene mutations in human haemoglobin: the chemical difference between normal and sickle cell haemoglobin. Nature. 1957; 180:326-8. [PubMed: 13464827]

3. Walters MC, Patience M, Leisenring W, et al. Bone marrow transplantation for sickle cell disease. N Engl J Med. 1996; 335:369-76. [PubMed: 8663884]

4. Vermylen C, Cornu G, Ferster A, et al. Haematopoietic stem cell transplantation for sickle cell anaemia: the first 50 patients transplanted in Belgium. Bone Marrow Transplant. 1998; 22:1-6. [PubMed: 9678788]

5. Bernaudin F, Socie G, Kuentz M, et al. Long-term results of related myeloablative stem-cell transplantation to cure sickle cell disease. Blood. 2007; 110:2749-56. [PubMed: 17606762]

6. Walters MC, Patience M, Leisenring W, et al. Stable mixed hematopoietic chimerism after bone marrow transplantation for sickle cell anemia. Biol Blood Marrow Transplant. 2001; 7:665-73. [PubMed: 11787529]

7. Iannone R, Casella JF, Fuchs EJ, et al. Results of minimally toxic nonmyeloablative transplantation in patients with sickle cell anemia and beta-thalassemia. Biol Blood Marrow Transplant. 2003; 9:519-28. [PubMed: 12931121]

8. Childs R, Chernoff A, Contentin N, et al. Regression of metastatic renal-cell carcinoma after nonmyeloablative allogeneic peripheral-blood stem-cell transplantation. N Engl J Med. 2000; 343:750-8. [PubMed: 10984562]

9. Srinivasan R, Takahashi Y, McCoy JP, et al. Overcoming graft rejection in heavily transfused and allo-immunised patients with bone marrow failure syndromes using fludarabine-based haematopoietic cell transplantation. Br J Haematol. 2006; 133:305-14. [PubMed: 16643433]

10. Powell JD, Lerner CG, Schwartz RH. Inhibition of cell cycle progression by rapamycin induces T cell clonal anergy even in the presence of costimulation. J Immunol. 1999; 162:2775-84. [PubMed: 10072524]

11. Powell JD, Fitzhugh C, Kang EM, Hsieh M, Schwartz RH, Tisdale JF. Low-dose radiation plus rapamycin promotes long-term bone marrow chimerism. Transplantation. 2005; 80:1541-5. [PubMed: 16371922]

12. Powars DR, Elliott-Mills DD, Chan L, et al. Chronic renal failure in sickle cell disease: risk factors, clinical course, and mortality. Ann Intern Med. 1991; 115:614-20. [PubMed: 1892333]

13. Gladwin MT, Sachdev V, Jison ML, et al. Pulmonary hypertension as a risk factor for death in patients with sickle cell disease. N Engl J Med. 2004; 350:886-95. [PubMed: 14985486]

14. Kang EM, Areman EM, David-Ocampo V, et al. Mobilization, collection, and processing of peripheral blood stem cells in individuals with sickle cell trait. Blood. 2002; 99:850-5. [PubMed: 11806986]

15. Bolan CD, Leitman SF, Griffith LM, et al. Delayed donor red cell chimerism and pure red cell aplasia following major ABO-incompatible nonmyeloablative hematopoietic stem cell transplantation. Blood. 2001; 98:1687-94. [PubMed: 11535498]

16. Griffith LM, McCoy JP Jr, Bolan CD, et al. Persistence of recipient plasma cells and anti-donor isohaemagglutinins in patients with delayed donor erythropoiesis after major $\mathrm{ABO}$ incompatible non-myeloablative haematopoietic cell transplantation. Br J Haematol. 2005; 128:668-75. [PubMed: 15725089]

17. Gilleece MH, Dexter TM. Effect of CAMPATH-1H antibody on human hematopoietic progenitors in vitro. Blood. 1993; 82:807-12. [PubMed: 7687895]

18. Kottaridis PD, Milligan DW, Chopra R, et al. In vivo CAMPATH-1H prevents graft-versus- host disease following nonmyeloablative stem cell transplantation. Blood. 2000; 96:2419-25. [PubMed: 11001893]

19. Siegal D, Xu W, Sutherland R, et al. Graft-versus-host disease following marrow transplantation for aplastic anemia: different impact of two GVHD prevention strategies. Bone Marrow Transplant. 2008; 42:51-6. [PubMed: 18372907]

20. Nollet F, Billiet J, Selleslag D, Criel A. Standardisation of multiplex fluorescent short tandem repeat analysis for chimerism testing. Bone Marrow Transplant. 2001; 28:511-8. [PubMed: 11593326] 
21. Anthi A, Machado RF, Jison ML, et al. Hemodynamic and functional assessment of patients with sickle cell disease and pulmonary hypertension. Am J Respir Crit Care Med. 2007; 175:1272-9. [PubMed: 17379852]

22. Hsieh MM, Link MB, Tisdale JF. Sirolimus associated pneumonitis after non-myeloablative peripheral blood stem cell transplant for sickle cell disease. Biol Blood Marrow Transplant. 2008; 14:256-7. [PubMed: 18215786]

23. Wierenga KJ, Hambleton IR, Lewis NA. Survival estimates for patients with homozygous sicklecell disease in Jamaica: a clinic-based population study. Lancet. 2001; 357:680-3. [PubMed: 11247552]

24. Steinberg MH, Barton F, Castro O, et al. Effect of hydroxyurea on mortality and morbidity in adult sickle cell anemia: risks and benefits up to 9 years of treatment. JAMA. 2003; 289:1645-51. [Erratum, JAMA 2003;290:756.]. [PubMed: 12672732]

25. Quinn CT, Rogers ZR, Buchanan GR. Survival of children with sickle cell disease. Blood. 2004; 103:4023-7. [PubMed: 14764527]

26. Powars DR, Chan LS, Hiti A, Ramicone E, Johnson C. Outcome of sickle cell anemia: a 4-decade observational study of 1056 patients. Medicine (Baltimore). 2005; 84:363-76. [PubMed: 16267411]

27. Morris EC, Rebello P, Thomson KJ, et al. Pharmacokinetics of alemtuzumab used for in vivo and in vitro T-cell depletion in allogeneic transplantations: relevance for early adoptive immunotherapy and infectious complications. Blood. 2003; 102:404-6. [PubMed: 12623851]

28. Rebello P, Cwynarski K, Varughese M, Eades A, Apperley JF, Hale G. Pharmacokinetics of CAMPATH-1H in BMT patients. Cytotherapy. 2001; 3:261-7. [PubMed: 12171714]

29. Cutler C, Li S, Ho VT, et al. Extended follow-up of methotrexate-free immunosuppression using sirolimus and tacrolimus in related and unrelated donor peripheral blood stem cell transplantation. Blood. 2007; 109:3108-14. [PubMed: 17138818]

30. Battaglia M, Stabilini A, Migliavacca B, Horejs-Hoeck J, Kaupper T, Roncarolo MG. Rapamycin promotes expansion of functional CD4+CD25+FOXP3+ regulatory T cells of both healthy subjects and type 1 diabetic patients. J Immunol. 2006; 177:8338-47. [PubMed: 17142730]

31. Coenen JJ, Koenen HJ, van Rijssen E, et al. Rapamycin, not cyclosporine, permits thymic generation and peripheral preservation of CD4+CD25+FoxP3+ T cells. Bone Marrow Transplant. 2007; 39:537-45. [PubMed: 17351648]

32. Powell JD, Zheng Y. Dissecting the mechanism of T-cell anergy with immunophilin ligands. Curr Opin Investig Drugs. 2006; 7:1002-7.

33. Kuypers DR. Benefit-risk assessment of sirolimus in renal transplantation. Drug Saf. 2005; 28:153-81. [PubMed: 15691225]

34. Stewart BL, Storer B, Storek J, et al. Duration of immunosuppressive treatment for chronic graftversus-host disease. Blood. 2004; 104:3501-6. [PubMed: 15292060]

35. Fraser CJ, Bhatia S, Ness K, et al. Impact of chronic graft-versus-host disease on the health status of hematopoietic cell transplantation survivors: a report from the Bone Marrow Transplant Survivor Study. Blood. 2006; 108:2867-73. [PubMed: 16788100] 


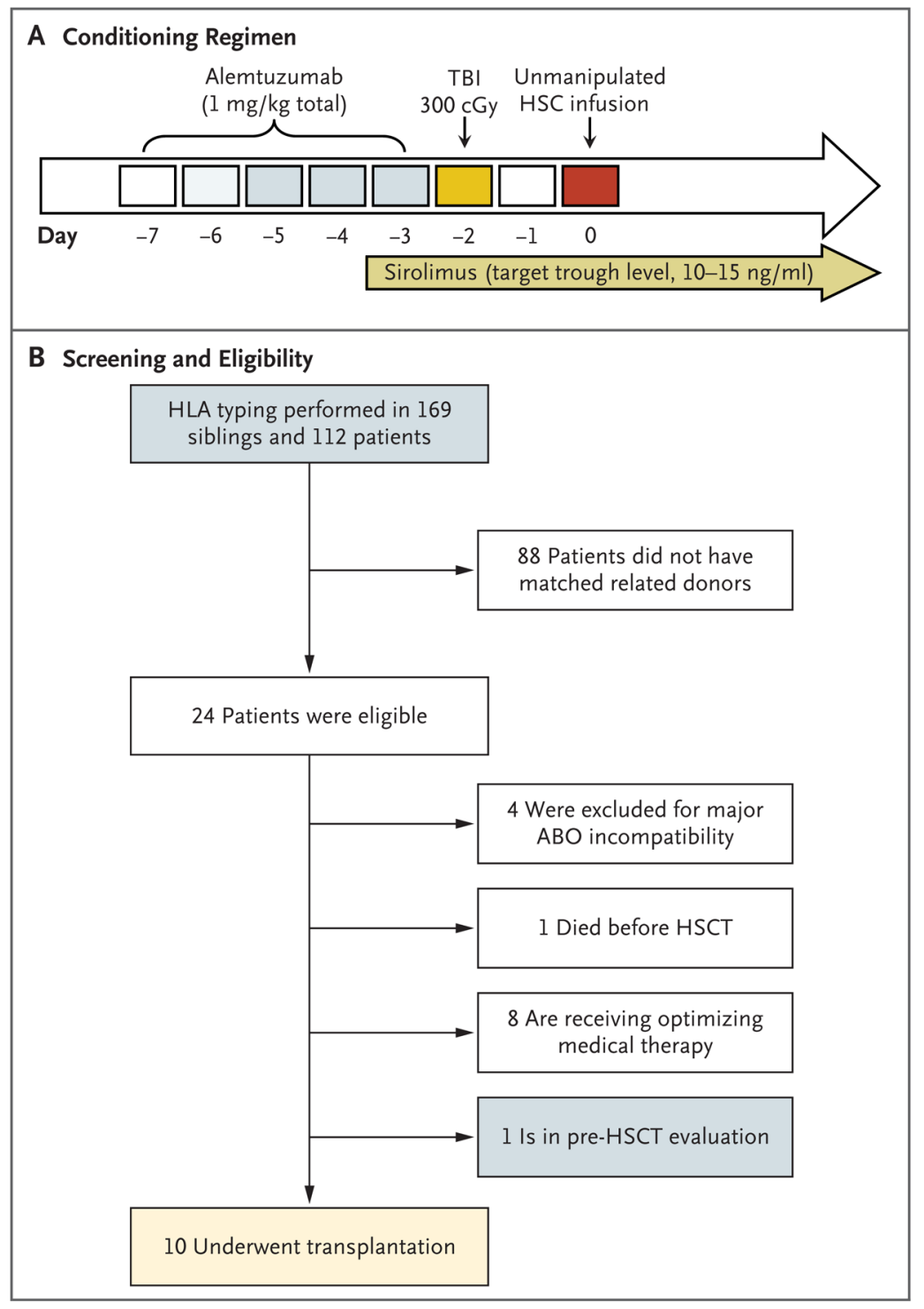

Figure 1. Conditioning Regimen and Screening of Patients

Panel A shows the conditioning regimen used before hematopoietic stem-cell transplantation (HSCT). The regimen consisted of alemtuzumab, at a total dose of $1 \mathrm{mg}$ per kilogram of body weight, given over a period of 5 days in gradually increasing doses: $0.03 \mathrm{mg}$ per kilogram (test dose) on day $-7,0.1 \mathrm{mg}$ per kilogram on day -6 , and then $0.3 \mathrm{mg}$ per kilogram per day on days -5 through -3 . A single dose of $300 \mathrm{cGy}$ of total-body irradiation (TBI) was administered on day -2 (with gonadal shielding applied for men). Treatment with oral sirolimus was initiated on day -1 at a dose of $5 \mathrm{mg}$ every 4 hours for three doses, then 5 mg daily starting on day 0, modified to achieve target trough levels of 10 to $15 \mathrm{ng}$ per milliliter of whole blood. Panel B shows the numbers of patients and their siblings who were screened, the number of eligible patients, and the number of patients who underwent transplantation. Among a total of 24 eligible patients, 6 of 6 HLA-matched siblings were identified. Four patients were excluded owing to major ABO incompatibility and a previously reported high incidence of pure red-cell aplasia from residual recipient lymphoid cells in nonmyeloablative HSCT, ${ }^{15,16}$ and one patient died of suspected sudden arrhythmia from severe iron overload 1 month before the planned HSCT. Eight patients are currently 
undergoing optimization of their medical therapy, including hydroxyurea therapy, iron chelation, and pain management, and one patient is currently undergoing evaluation for HSCT. 


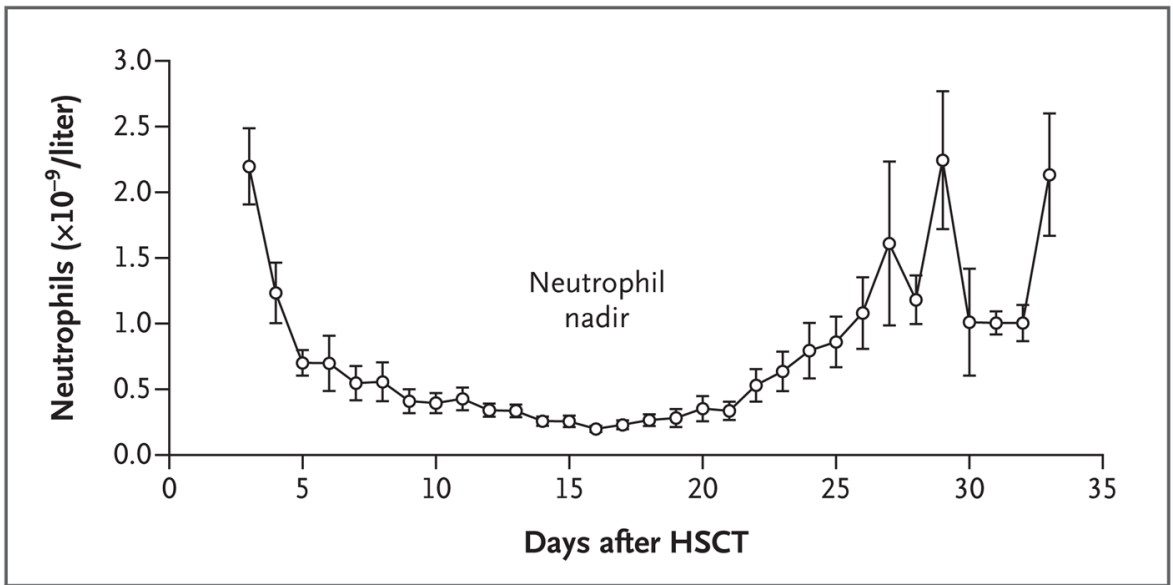

Figure 2. Neutrophil Counts after Hematopoietic Stem-Cell Transplantation (HSCT) Each circle represents the mean neutrophil count for all patients after the transplantation procedure. I bars indicate standard errors. 


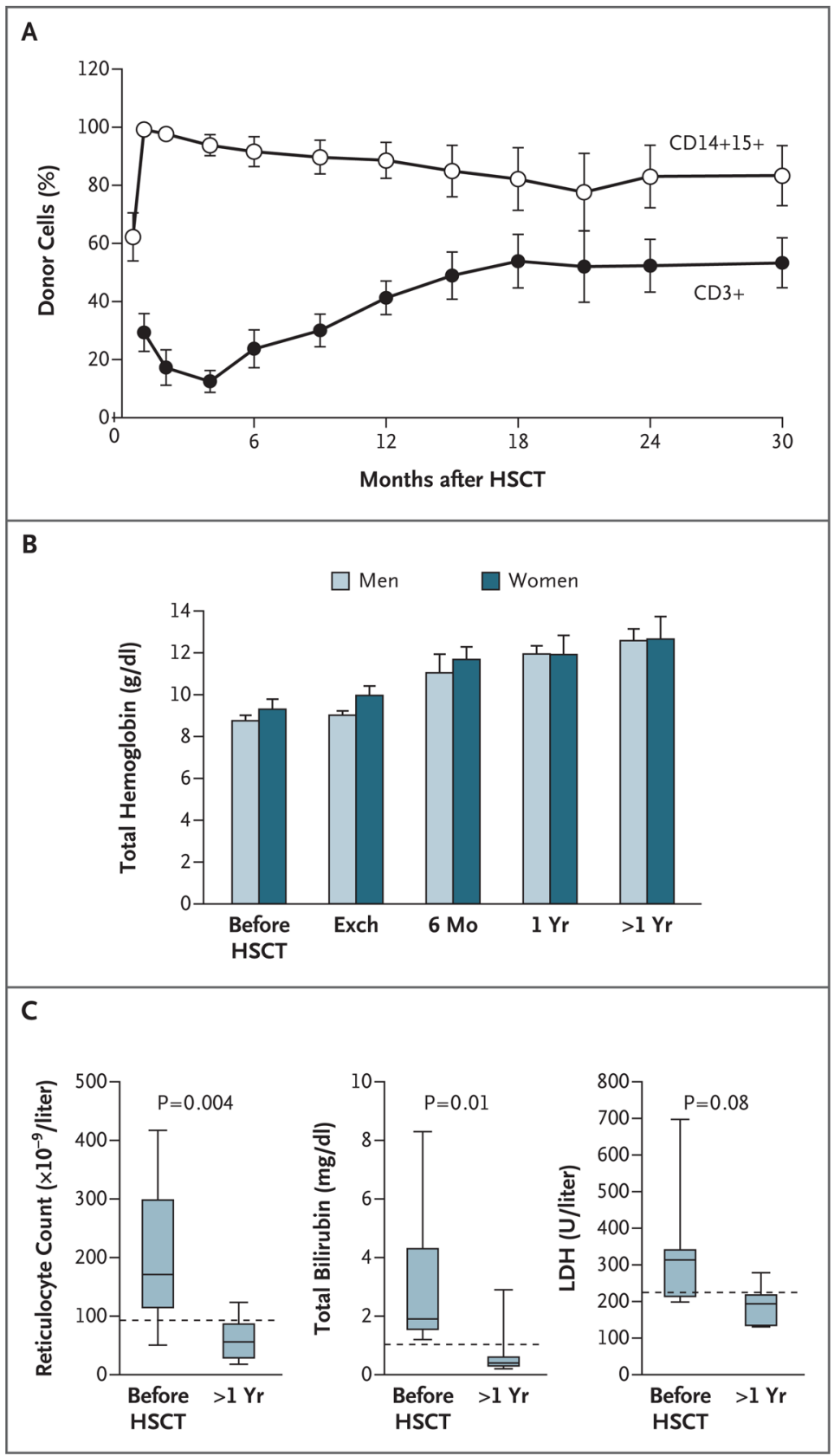

Figure 3. Donor-Cell Chimerism and Laboratory Measurements after Hematopoietic Stem-Cell Transplantation

Panel A shows the mean $( \pm \mathrm{SE})$ percentage of donor cells after hematopoietic stem-cell transplantation (HSCT). Donor chimerism among CD3+ T cells and CD14+15+ myeloid cells was assessed by means of a polymerase-chain-reaction assay to determine minisatellite polymorphisms between patient and donor. Panel B shows the laboratory measurements obtained one month before HSCT and those obtained at the most recent follow-up (median, 30 months; range, 15 to 54). The bar graphs in Panel B show mean values for total hemoglobin before, during (Exch), and after HSCT for male and female recipients; T bars indicate standard errors. For the reticulocyte count, total bilirubin level, and lactate dehydrogenase (LDH) level shown in Panel C, the horizontal lines within the box plots 
indicate the mean values, the lower and upper ends of the boxes represent the 25th and 75th percentiles, and the I bars represent the 10th and 90th percentiles; the dashed lines represent the upper limits of the reference ranges. 


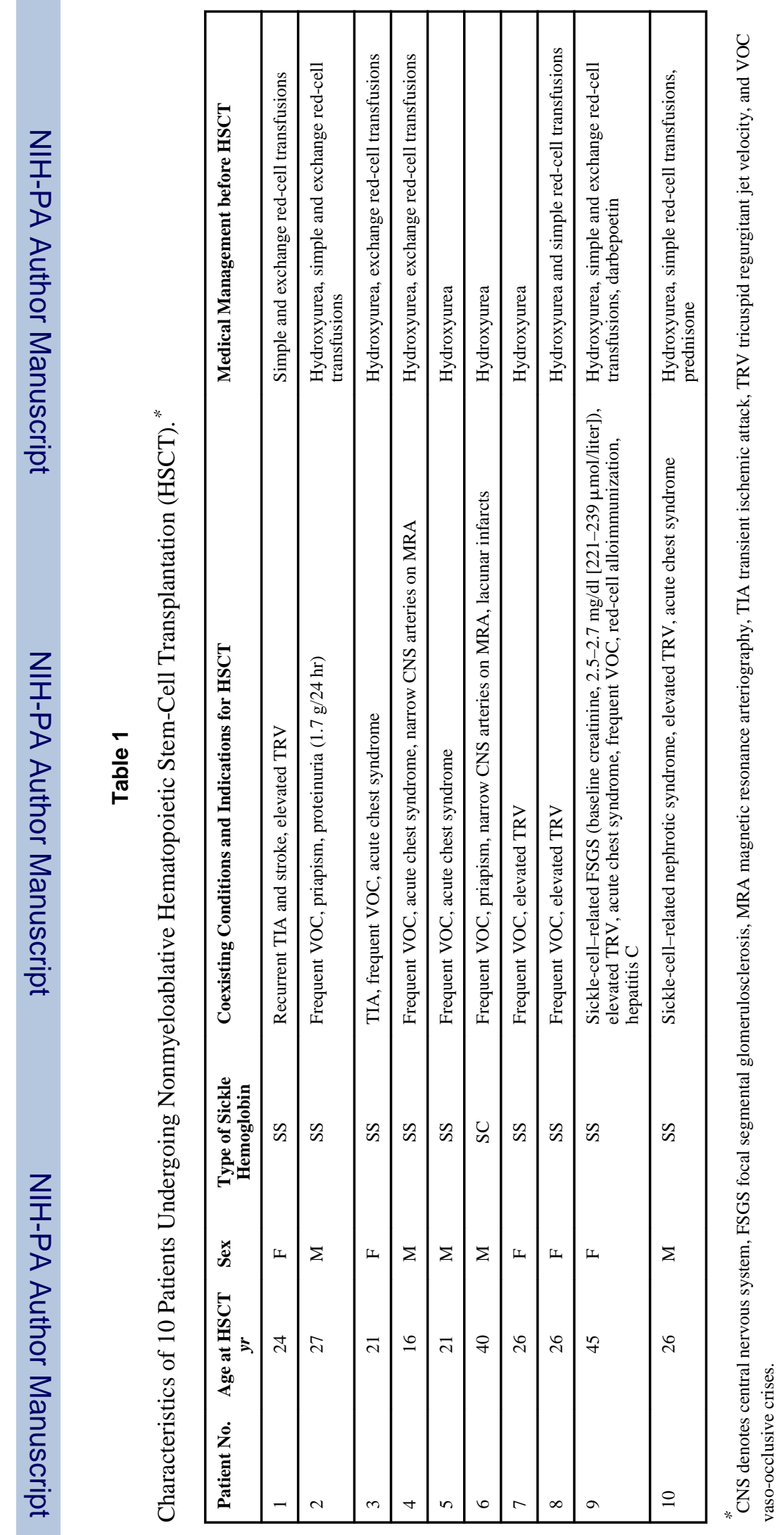

N Engl J Med. Author manuscript; available in PMC 2013 April 16. 


$$
[i
$$


Table 3

Summary of Serious Adverse Events. *

\begin{tabular}{|c|c|c|c|}
\hline Event & $\begin{array}{l}\text { Interval between } \\
\text { HSCT and Event }\end{array}$ & No. of Patients & Treatment and Outcome \\
\hline $\mathrm{CMV}$ reactivation & 14 days & 1 & $\begin{array}{l}300 \text { copies of } \mathrm{CMV} \text { genome; treated with } 1 \text { wk of } \\
\text { intravenous foscarnet, followed by maintenance therapy } \\
\text { with oral valacyclovir }\end{array}$ \\
\hline Narcotic-withdrawal syndrome & $\begin{array}{l}\text { Various times during } \\
\text { the first } 6 \text { mo }\end{array}$ & 3 & $\begin{array}{l}\text { Hospital admission for tapering of narcotics; in all } 3 \\
\text { patients, narcotics have been withdrawn }\end{array}$ \\
\hline \multicolumn{4}{|l|}{ Abdominal pain } \\
\hline Gastric ulcer on gastroscopy & $3 \mathrm{mo}$ & 1 & Proton-pump-inhibitor therapy for $1 \mathrm{mo}$ \\
\hline Unknown cause & $12 \mathrm{mo}$ & 1 & Self-limited; no treatment \\
\hline \multicolumn{4}{|l|}{ Sirolimus-associated complications } \\
\hline \multicolumn{4}{|l|}{ Pneumonitis } \\
\hline Patient 3 & $16 \mathrm{mo}$ & 1 & $\begin{array}{l}\text { When sirolimus was switched to cyclosporine, the } \\
\text { pneumonitis completely resolved }\end{array}$ \\
\hline Patient 9 & $4 \mathrm{mo}$ & 1 & $\begin{array}{l}\text { When the sirolimus dose was decreased to achieve a } \\
\text { trough level of } 5 \mathrm{ng} / \mathrm{ml} \text {, the pneumonitis completely } \\
\text { resolved }\end{array}$ \\
\hline \multicolumn{4}{|l|}{ Arthralgias } \\
\hline Patient 9 & $3 \mathrm{mo}$ & 1 & $\begin{array}{l}\text { Supportive care; target trough level reduced to } 5 \mathrm{ng} / \mathrm{ml} \text {; } \\
\text { patient was admitted for arthralgia workup }\end{array}$ \\
\hline Patient 1 & $4 \mathrm{mo}$ & 1 & $\begin{array}{l}\text { Supportive care; target trough level reduced to } 5 \mathrm{ng} / \mathrm{ml} \text {; } \\
\text { patient remained an outpatient }\end{array}$ \\
\hline Transfusion-associated babesiosis & $8 \mathrm{mo}$ & 1 & $\begin{array}{l}\text { Azithromycin and atovaquone; condition resolved } \\
\text { completely }\end{array}$ \\
\hline Exercise-related rhabdomyolysis & $3 \mathrm{mo}$ & 1 & $\begin{array}{l}\text { Hydration and switch from oral sulfamethoxazole- } \\
\text { trimethoprim to inhaled pentamidine }\end{array}$ \\
\hline Ventricular tachycardia & $\begin{array}{l}1 \text { mo before } \\
\text { transplantation and } \\
\text { during conditioning } \\
\text { regimen }\end{array}$ & 1 & $\begin{array}{l}\text { Due to iron overload and previous cardiac ischemia; } \\
\text { rate controlled with amiodarone; patient is currently } \\
\text { receiving carvedilol }\end{array}$ \\
\hline Clostridium difficile colitis & $4 \mathrm{mo}$ & 1 & Supportive care; antibiotics \\
\hline Cholelithiasis-induced acute pancreatitis & $15 \mathrm{mo}$ & 1 & Supportive care \\
\hline Fever & $1 \mathrm{mo}$ & 1 & Supportive care \\
\hline
\end{tabular}

* CMV denotes cytomegalovirus, GVHD graft-versus-host disease, and HSCT hematopoietic stem-cell transplantation. 